\title{
The human bitumen study hits the headlines
}

\author{
C. Van Thriel $\cdot$ R. Marchan
}

Published online: 30 October 2012

(c) Springer-Verlag Berlin Heidelberg 2012

Besides the current cutting-edge topics in toxicology, such as oxidative stress research (Baird and Dinkova-Kostova 2011; Barcelos et al. 2011; Cadenas et al. 2010), metal toxicity (Antonini et al. 2011; Bolt et al. 2011; Sinicropi et al. 2010), nanotoxicology (Weiss and Diabaté 2011), in vitro systems (Heise et al. 2012; Knobeloch et al. 2012; Zellmer et al. 2010), and modelling (Mielke et al. 2011; Hoehme et al. 2010), bitumen research has led an essentially wallflower existence. Fortunately, this has dramatically changed since the recent publications from the Human Bitumen Study (Schlüter 2011; Raulf-Heimsoth et al. 2011a). Bitumen was already regarded as a suspected carcinogen in the 1980s (Schlüter 2011; Greim 2001). However, the discussion surrounding bitumen exposure as a potential health hazard was always controversial. On the one side, a long-term carcinogenicity study with dermal application yielded positive results (Sivak et al. 1997). Conversely, a long-term inhalation study-probably the more relevant route of application-did not lead to increased tumour incidence in rats (Fuhst et al. 2007). Furthermore, a small biomonitoring study did not show increased levels of DNA strand breaks in lymphocytes of bitumen workers (Fuchs et al. 1996). However, some evidence of increased DNA damage was found in roofers who process bitumen at higher temperatures (Fuchs et al. 1996). Therefore, key questions are whether bitumen causes genotoxicity in exposed workers and whether inhalation is toxic to the airways. The recently published Human Bitumen Study is the largest worldwide and best-controlled study in this field, encompassing 500 exposed workers from 80 construction sites. The results, in a nutshell, show that DNA adducts and strand breaks in bitumen workers were within the range found in healthy individuals. On the other hand, bitumen workers showed chronic inflammation in the lower airways. The practical consequences for both industry and occupational medicine include the need to reduce the processing temperature of bitumen as much as possible, as temperature represents the most critical factor influencing bitumen vapour exposure. Finally, follow-up studies are needed to assess the relevance of the identified airway inflammation. In particular, the relevance of subtle changes of inflammatory mediators in the lower airways (e.g. interleukins) is of general importance in chemically induced airway inflammation and currently discussed in regulatory toxicology. To give our readers a rapid overview, we summarised the key findings of the Human Bitumen Study (Table 1).
C. Van Thriel · R. Marchan $(\bowtie)$

Leibniz Institut für Arbeitsforschung an der TU Dortmund, Leibniz Research Centre for Working Environment and Human Factors (IfADo), Ardeystrasse 67, 44139 Dortmund, Germany e-mail: marchan@ifado.de 
Table 1 Key messages of the cross-shift design study of bitumen-exposed workers

Key result $\quad$ Reference

This article summarises the most important findings of the Human Bitumen Study which includes 500 workers Raulf-Heimsoth et al. (2011a) from 80 construction sites. The results in a nutshell: Bitumen exposure did not cause genotoxicity but subchronic inflammation of the upper airways

Quantification of bitumen-derived matter in aerosols still remains a challenge and differences in sampling and analytical methods should be considered. PAH exposure for mastic asphalt workers was higher compared to construction sites without bitumen application. However, the exposure of coke-oven workers is at least one order of magnitude higher when compared to bitumen workers

Processing temperature of bitumen is critical for exposure. Therefore, reducing the processing temperature represents an efficient protective measure

Urinary levels of PAHs are only of limited value when it comes to the biomonitoring of bitumen-exposed workers, because (1) the PAH content of bitumen is relatively low, (2) cigarette smoking has a strong influence, and (3) additives are increasingly used in asphalt mixtures

Bitumen-exposed workers showed potentially (sub) chronic irritative inflammatory effects in the lower airways

DNA adducts and strand breaks in bitumen workers were within the range found in healthy individuals, although slightly higher in exposed workers compared to non-exposed controls. Overall, it is unlikely that bitumen exposure at the workplaces causes DNA damage

Bitumen exposure did not cause a relevant increase in micronucleus frequencies in peripheral blood lymphocytes of workers

The influence of 18 SNPs on urinary PAH metabolites was relatively weak, with the GSTM1 deletion and NAT2- and CYP1A1-associated variants showing borderline significant effects

Mastic asphalt application led to significantly higher bitumen vapour exposure than rolled asphalt application Raulf-Heimsoth et al. (2011c)

\section{References}

Antonini JM, Roberts JR, Stone S, Chen BT, Schwegler-Berry D, Chapman R, Zeidler-Erdely PC, Andrews RN, Frazer DG (2011) Persistence of deposited metals in the lungs after stainless steel and mild steel welding fume inhalation in rats. Arch Toxicol 85(5):487-498

Baird L, Dinkova-Kostova AT (2011) The cytoprotective role of the Keap1-Nrf2 pathway. Arch Toxicol 85(4):241-272

Barcelos GR, Grotto D, Serpeloni JM, Angeli JP, Rocha BA, de Oliveira Souza VC, Vicentini JT, Emanuelli T, Bastos JK, Antunes LM, Knasmüller S, Barbosa F Jr (2011) Protective properties of quercetin against DNA damage and oxidative stress induced by methylmercury in rats. Arch Toxicol 85(9):11511157

Bolt HM, Marchan R, Hengstler JG (2011) Selenium: an element with two faces. Arch Toxicol 85(12):1493-1494

Breuer D, Hahn JU, Höber D, Emmel C, Musanke U, Rühl R, Spickenheuer A, Raulf-Heimsoth M, Bramer R, Seidel A, Schilling B, Heinze E, Kendzia B, Marczynski B, Welge P, Angerer J, Brüning T, Pesch B (2011) Air sampling and determination of vapours and aerosols of bitumen and polycyclic aromatic hydrocarbons in the human bitumen study. Arch Toxicol 85(Suppl 1):S11-S20

Cadenas C, Franckenstein D, Schmidt M, Gehrmann M, Hermes M, Geppert B, Schormann W, Maccoux LJ, Schug M, Schumann A, Wilhelm C, Freis E, Ickstadt K, Rahnenführer J, Baumbach JI, Sickmann A, Hengstler JG (2010) Role of thioredoxin reductase 1 and thioredoxin interacting protein in prognosis of breast cancer. Breast Cancer Res 12(3):R44

Fuchs J, Hengstler JG, Boettler G, Oesch F (1996) Primary DNA damage in peripheral mononuclear blood cells of workers exposed to bitumen-based products. Int Arch Occup Environ Health 68(3):141-146

Fuhst R, Creutzenberg O, Ernst H, Hansen T, Pohlmann G, Preiss A, Rittinghausen S (2007) 24 Month inhalation carcinogenicity study of bitumen fumes in Wistar (WU) rats. J Occup Environ Hygiene 4:20-43

Greim H (2001) Gesundheitsschädliche Arbeitsstoffe. Bitumen (Dampf und Aerosol). Toxikologisch-arbeitsmedizinische Begründungen von MAK-Werten. Lfg. Wiley-VCH, Weinheim, p 32

Heise T, Schug M, Storm D, Ellinger-Ziegelbauer H, Ahr HJ, Hellwig B, Rahnenfuhrer J, Ghallab A, Guenther G, Sisnaiske J, Reif R, Godoy P, Mielke H, Gundert-Remy U, Lampen A, Oberemm A, Hengstler JG (2012) In vitro-in vivo correlation of gene expression alterations induced by liver carcinogens. Curr Med Chem 19(11):1721-1730

Hoehme S, Brulport M, Bauer A, Bedawy E, Schormann W, Hermes M, Puppe V, Gebhardt R, Zellmer S, Schwarz M, Bockamp E, Timmel T, Hengstler JG, Drasdo D (2010) Prediction and validation of cell alignment along microvessels as order principle to restore tissue architecture in liver regeneration. Breast Cancer Res 12(3):R44

Knobeloch D, Ehnert S, Schyschka L, Büchler P, Schoenberg M, Kleeff J, Thasler WE, Nussler NC, Godoy P, Hengstler J, Nussler AK (2012) Human hepatocytes: isolation, culture, and quality procedures. Methods Mol Biol 806:99-120

Marczynski B, Raulf-Heimsoth M, Spickenheuer A, Pesch B, Kendzia B, Mensing T, Engelhardt B, Lee EH, Schindler BK, Heinze E, Welge P, Bramer R, Angerer J, Breuer D, Käfferlein HU, Brüning $\mathrm{T}$ (2011) DNA adducts and strand breaks in workers exposed to vapours and aerosols of bitumen: associations between exposure and effect. Arch Toxicol 85(Suppl 1):S53-S64

Mielke H, Anger LT, Schug M, Hengstler JG, Stahlmann R, GundertRemy U (2011) A physiologically based toxicokinetic modelling approach to predict relevant concentrations for in vitro testing. Arch Toxicol 85(6):555-563

Pesch B, Spickenheuer A, Kendzia B, Schindler BK, Welge P, Marczynski B, Rihs HP, Raulf-Heimsoth M, Angerer J, Brüning $\mathrm{T}$ (2011) Urinary metabolites of polycyclic aromatic hydrocarbons in workers exposed to vapours and aerosols of bitumen. Arch Toxicol 85(Suppl 1):S29-S39 
Raulf-Heimsoth M, Pesch B, Rühl R, Brüning T (2011a) The Human Bitumen Study: executive summary. Arch Toxicol 85(Suppl 1): S3-S9

Raulf-Heimsoth M, Pesch B, Kendzia B, Spickenheuer A and Bramer $\mathrm{R}$, et al. (2011b) Irritative effects of vapours and aerosols of bitumen on the airways assessed by non-invasive methods. Arch Toxicol 85 (Suppl1):S41-52

Raulf-Heimsoth M, Marczynski B, Spickenheuer A, Pesch B and Welge $P$ et al (2011c) Bitumen workers handling mastic versus rolled asphalt in a tunnel: assessment of exposure and biomarkers of irritation and genotoxicity. Arch Toxicol 85 (Suppl1):S81-S87

Rihs HP, Spickenheuer A, Heinze E, Pesch B, Raulf-Heimsoth M, Angerer J, Brüning T (2011) Modulation of urinary polycyclic aromatic hydrocarbon metabolites by enzyme polymorphisms in workers of the German human bitumen Study. Arch Toxicol 85(Suppl 1):S73-S79

Schlüter G (2011) Bitumen: a challenge for toxicology and occupational health. Arch Toxicol 85(Suppl 1):S1-S2

Sinicropi MS, Amantea D, Caruso A, Saturnino C (2010) Chemical and biological properties of toxic metals and use of chelating agents for the pharmacological treatment of metal poisoning. Arch Toxicol 84(7):501-520

Sivak A, Niemeier R, Lynch D, Beltis K, Simon S, Salomon R, Latta R, Belinky B, Menzies K, Lunsford A, Cooper C, Ross A,
Bruner R (1997) Skin carcinogenicity of condensed asphalt roofing fumes and their fractions following dermal application to mice. Cancer Lett 117(1):113-123

Spickenheuer A, Rühl R, Höber D, Raulf-Heimsoth M, Marczynski B, Welge P, Breuer D, Gabriel S, Musanke U, Rode P, Heinze E, Kendzia B, Bramer R, Knecht U, Hahn JU, Brüning T, Pesch B (2011) Levels and determinants of exposure to vapours and aerosols of bitumen. Arch Toxicol 85(Suppl 1):S21-S28

Weiss C, Diabaté S (2011) A special issue on nanotoxicology. Arch Toxicol 85(7):705-706

Welge P, Marczynski B, Raulf-Heimsoth M, Spickenheuer A, Kendzia B, Heinze E, Angerer J, Käfferlein HU, Pesch B, Brüning T (2011) Assessment of micronuclei in lymphocytes from workers exposed to vapours and aerosols of bitumen. Arch Toxicol 85(Suppl 1):S65-S71

Zellmer S, Schmidt-Heck W, Godoy P, Weng H, Meyer C, Lehmann T, Sparna T, Schormann W, Hammad S, Kreutz C, Timmer J, von Weizsäcker F, Thürmann PA, Merfort I, Guthke R, Dooley S, Hengstler JG, Gebhardt R (2010) Transcription factors ETF, E2F, and SP-1 are involved in cytokine-independent proliferation of murine hepatocytes. Hepatology 52(6):2127-2136 